This item was submitted to Loughborough's Research Repository by the author.

Items in Figshare are protected by copyright, with all rights reserved, unless otherwise indicated.

\title{
Birth weight and body composition in 6-to-8 years old Maya children
}

\section{PLEASE CITE THE PUBLISHED VERSION}

https://doi.org/10.1002/ajhb.23542

\section{PUBLISHER}

Wiley

\section{VERSION}

AM (Accepted Manuscript)

\section{PUBLISHER STATEMENT}

This is the peer reviewed version of the following article: AZCORRA, H., VARELA-SILVA, M.I. and DICKINSON, F., 2020. Birth weight and body composition in 6-to-8 years old Maya children. American Journal of Human Biology, 33(6): e23542, doi: 10.1002/ajhb.23542, which has been published in final form at https://doi.org/10.1002/ajhb.23542. This article may be used for non-commercial purposes in accordance with Wiley Terms and Conditions for Use of Self-Archived Versions.

\section{LICENCE}

CC BY-NC-ND 4.0

\section{REPOSITORY RECORD}

Azcorra, Hugo, Ines Varela-Silva, and Federico Dickinson. 2020. "Birth Weight and Body Composition in 6-to8 Years Old Maya Children". Loughborough University. https://hdl.handle.net/2134/13259600.v1. 


\section{Birth weight and body composition in 6-to-8 years old Maya children}

Hugo Azcorra' ${ }^{1}$, Maria Inês Varela-Silva ${ }^{2}$, Federico Dickinson ${ }^{3}$

1: Centro de Investigaciones Silvio Zavala, Universidad Modelo

Mérida, Yucatán, México

Carretera a Cholul 200 metros periférico norte, C.P. 97310

2: Loughborough University - School of Sport, Exercise and Health Sciences Loughborough, LE11 3TU, UK.

3: Departamento de Ecología Humana, Cinvestav-Mérida

Antigua carretera a Progreso $\mathrm{km} 6$

Mérida, México, C. P. 97310

Abbreviated title: Birth weight and body composition in Maya children

Corresponding autor:

Hugo Azcorra

Centro de Investigaciones Silvio Zavala, Universidad Modelo

Mérida, Yucatán, México

Carretera a Cholul 200 metros periférico norte, C.P. 97310

\section{hugoazpe@hotmail.com}

The data reported here were collected as part of a project funded by the National Science and Technology Council of Mexico; Consejo Nacional de Ciencia y Tecnología de México (Conacyt). Contract grant number: 168047. 


\section{ABSTRACT}

Objective: To test the hypothesis that fetal growth, indexed by birth weight (BW), induce metabolic adjustments in the fetus that will be reflected in differences in body composition in a sample of 6-to 8-years old urban Maya children from Yucatan, Mexico.

Methods: We measured height $(\mathrm{cm})$, weight $(\mathrm{kg})$ and triceps skinfold $(\mathrm{mm})$ in 260 children (boys: 132, girls: 128$)$, and height $(\mathrm{cm})$ and weight $(\mathrm{kg})$ in their mothers. Body composition was estimated in children through bioelectrical impedance analysis. Outcome variables were fat free-mass index (FFMI= fat-free mass $[\mathrm{kg}] /$ height $\left.[\mathrm{m}]^{2}\right)$ and fat mass index $\left(\mathrm{FMl}=\right.$ fat mass $[\mathrm{kg}] /$ height $\left.[\mathrm{m}]^{2}\right)$. The main independent variable was BW z-scores. Multiple linear regression models were used to analyze the association between BW z-scores and outcome variables measured during childhood. Separate analyses were done for boys and girls. Complementary models were run using outcomes as z-scores. Models were adjusted for location, children's and mothers' age, mother's body mass index and household overcrowding index.

Results: BW in boys was positively associated with FFMI and FMI. FFMI increase $0.34 \mathrm{~kg} / \mathrm{m}^{2}$ per $1-\mathrm{SD}$ increase in BW and FMI increase $0.40 \mathrm{~kg} / \mathrm{m}^{2}$ per $1-\mathrm{SD}$ increase in BW. When outcomes were used as z-scores, FFMI increase 0.24 SD and FMI increase 0.18 SD per 1-SD increase in BW, respectively.

Conclusion Our results are in contrast with previous findings that birth weight is more consistently associated with subsequent lean mass than with fat mass. Associations, detected only in boys, may be explained by sex differences in sensitivity to early life environments.

Key words: birth weight, body composition, phenotypic induction, Maya 


\section{INTRODUCTION}

Phenotypic induction, also known as programming, has been defined as the capacity of any environmental stimuli, present during critical stages of early development, to generate long-term effects on the structure or physiology of the organism (Bateson, 2001). Phenotypic induction has been recognized as a process that links early life experiences with cardiometabolic diseases in adulthood (Wells, 2012), and elements of body composition (e.g. lean and body fat mass) seem to play an important role shaping disease susceptibility in individuals (Calella, Galle, Fornelli, Liguori, \& Valerio, 2020; Latt, Mäestu, \& Jürimäe 2018).

Conditions experienced during intrauterine development are particularly relevant in the induction or programming of body composition and metabolism during postnatal life (Wells, Chomto, \& Fewtrell, 2007). Birth weight, a crude parameter for fetal growth, has been commonly used as a proxy measure of the quality of nutritional conditions experienced by the organism during gestation. During the first months of pregnancy, the mother provides the nutrients and oxygen required for the formation and growth of vital and metabolically relevant organs, as well as muscle tissue development (Bogin, 1999). During the last stage of pregnancy, nutrients transferred to the fetus start to be accumulated in fat deposits to prepare for the several challenges of postnatal life, including termoregulation and the transition from placental to oral nutrition (Kuzawa, 1998).

Several studies have analyzed the relationship between birth weight and body composition at different stages of postnatal life. Studies have consistently shown positive associations between birth weight and subsequent lean body mass and a smaller number of studies have shown associations (both positive and negative) with body fat mass (Wells et al., 2007). Some studies have found that birth weight is associated with body fat only in females ( $\mathrm{Li}$, Stein, Barnhart, Ramakrishnan, \& Martorell, 2003; Sachdev et al., 2005; Rogers et al., 2006). Most of studies associating size at birth with body composition during childhood have been conducted in populations from high-income countries, mainly in the UK and the USA (Okosun, Liao, Rotimi, Dever, \& Cooper, 2000; Fewtrell, Lucas, Cole, \& 
Wells, 2004; Rogers et al., 2006). Fewer studies have addressed the link between birth weight and body composition outcomes among indigenous populations in lowand- middle income countries (Bavdekar et al., 1999; Li et al., 2003), whose chronic disadvantaged living conditions strongly impact maternal nutritional phenotype and their offspring size at birth.

The period of growth during which the organism is exposed to a given environment appear to be important in the induction of body composition outcomes. The intrauterine stage seems to be particularly important in the induction of lean body mass given that organogenesis occurs during this period. In contrast, the first years of postnatal growth are relevant in the induction of fat mass due to exposure to greater number of environmental factors that impact metabolism (Wells, 2007a). However, nutritional environment during gestation may induce variability in body fatness in postnatal life through long term changes in the regulation of several components of energy balance (Metges, 2009).

Whitin the framework of human biology, the rationale for this study is to contribute to the understanding of how conditions experienced at early stages of development shape variation in phenotype during childhood, in populations with a long history of poverty and who are currently experiencing abrupt changes in their lifestyle, such as the Maya.

The Maya are the largest indigenous group in the American continent (CDI, 2017). The Yucatan Peninsula, in Mexico, is home to a great number of Maya people resident in urban and rural communities (INEGI, 2015a). The Maya population of Yucatán has lived, since Colonial times, in conditions of serious poverty and oppression. During the European domination, the Maya lived under a political system that functioned on the basis on a slave-like payment tribute system and forced labor. Following the Mexican Independence, during the $19^{\text {th }}$ century and up to the 1920's, a large number of Maya were employed in the production of sugar cane, livestock and the sisal agro-industry, but their living conditions did not improve (Bracamonte, 2007). Since the second half of the $20^{\text {th }}$ century, a considerable proportion of Maya people moved into very low paid jobs in urban 
settings, due to the colapse of the sisal industry and government policies relating to national and global economy (Ramírez-Carrillo, 2020). Recent estimations suggest that almost $70 \%$ of Maya families live in conditions of poverty (Bracamonte \& Lizama, 2006). In urban locations, the Maya work mostly in construction, manufacturing, domestic, commercial and transport jobs, as low-wage employees. Their long history of marginalization and poverty have contributed to the presence of high rates of chronic undernutrition (Dickinson, Cervera, Murguia \& Uc, 1990) and their recent integration into the national and global consumer market has increased the rates of overweight and obesity in children and adults (Bogin, AvilaEscalante, Castillo-Burguete, Azcorra, \& Dickinson, 2020). Besides, Maya infants from Yucatan show lower mean values of birth weight than their non-Maya counterparts (Azcorra, Vázquez-Vázquez, Méndez, Salazar, \& Datta Banik, 2016).

In this study we aim to test the hypothesis that fetal growth, indexed by birth weight, induce metabolic adjustments in the fetus that will be reflected in differences in body composition during childhood. We test this hypothesis in a sample of 6-to 8-years old urban Maya children from Yucatan. This study also aims to contribute to the debate about the factors that may explain the high rates of adiposity among the Maya. We have previously reported that around $30 \%$ of children of this sample met the criteria for excessive values of body mass index (BMI), waist circumference and triceps, suprailiac and subscapular skinfolds (Azcorra et al., 2019). We now add other body composition measures to further the discussion on early factors involved in the programming of body composition parameters during childhood.

\section{METHODS}

Data used in this study was withdrawn from a cross-sectional and intergenerational research project conducted between September 2011 and January 2014 in the state of Yucatan, in Mexico. This included 260 Maya children (6-to-8 years old) and their biological mothers from the cities of Merida (the capital city) and Motul. By 2015 , Merida was inhabited by 892,363 people, with a Maya population of around $11 \%$. Motul, located in the north-central region of the state, was, in 2015 , inhabited 
by 36,097 people; $25 \%$ of them were Maya (INEGI, 2015a). Merida and Motul differ in population size and in some aspects of economic activities, but children's families in our sample from both locations are not different in any relevant socioeconomic characteristics, such as mean family size (Merida: 5.14 vs Motul: 5.02), number of offspring (Merida: 2.42 vs Motul: 2.43) and mean of household overcrowding index (Merida: 3.01 vs Motul: 3.25 ). In both cities, the mother-child dyads were recruited in primary schools attended by the children. In Merida, participants were recruited in 47 schools from low-income neighbourhoods, with a high concentration of Maya families. In Motul, the mother-child dyads were recruited in the 12 public primary schools of the city. According to the National Institute of Geography and Statistics, $98.7 \%$ of children between 6 and 11 years of age in Yucatan attend primary school (INEGI, 2015b), and the percentage of attendance in urban setting, such as Merida and Motul is higher. Therefore, we are certain that all childen meeting the inclusion criteria similar had the same chances to be included in the study. The presence of maternal and paternal Maya surnames in children and their mothers was used as the criteria to attribute Maya ancestry. This is a common way to attribute ancestry and has been explained in details elsewhere (Colantonio, Lasker, Kaplan, \& Fuster, 2003; Relethford, 1995).

\section{Physical measurements and body composition}

Children's height $(\mathrm{cm})$, weight $(\mathrm{kg})$ and triceps skinfold $(\mathrm{mm})$, and their mothers' height $(\mathrm{cm})$ and weight $(\mathrm{kg})$ were measured following standardized procedures (Lohman, Roche, \& Martorell, 1998). Bioelectric impedance analysis (BIA) was conducted in children using a portable Bodystat 1500 Monitoring Unit to estimate body composition indicators, using equations developed by Ramirez et al. (2012). We estimated fat-free mass (FFM) and fat mass (FM) and then converted to fatfree mass index (FFMI= FFM $[\mathrm{kg}] /$ height $\left.[\mathrm{m}]^{2}\right)$ and fat mass index (FMI= FM $[\mathrm{kg}] /$ height $[\mathrm{m}]^{2}$ ), respectively. We also calculated body fat percentage in children $(B F \%=F M[k g] \times 100 /$ weight $[\mathrm{kg}]$ ) with the purpose of describing the level of adiposity, although there are no standards or references for $\mathrm{BF} \%$ appropriate for Mexican children. We selected FFMI and FMI as outcome variables rather than 
percentages or absolute mass because FFMI and FMI are adjusted for variation in body size.

The BIA equations used were:

(1) FFM $(\mathrm{kg})=0.661 \times$ height $(\mathrm{cm})^{2} /$ resistance $($ ohms $)+0.200 \times$ weight $(\mathrm{kg})-$ 0.320

(2) $F M(k g)=$ weight $(\mathrm{kg})-F F M(k g)$

Mothers were measured and interviewed during homevisits to obtain anthropometric, demographic and socioeconomic data. Mothers' BMI was used as a covariate in the analyses. Household crowding index (number of people living in the house/number of rooms used to sleep) was used as a proxy for living conditions in the family (Krieger \& Higgins, 2002). Children's birth weight was obtained from birth certificates given to the mothers at the time of hospital discharge.

\section{Data analyses}

No significant differences were found in socioeconomic characteristics of the family, children's birthweight and maternal anthropometric characteriscs between participants from Merida and Motul. Therefore, the data presented in this study derives from a combined sample from both locations. Student's independent $t$-tests were used to compare anthropometric, body composition and maternal characteristics between boys and girls. The association between birth weight and body composition was analysed through multiple linear regressions models. Separated models were performed for boys and girls. Birth weight, FFMI and FMI were transformed to internal sex-specific z-scores using sample statistics $(Z=x-$ $\mu / \sigma$, where $Z$ is $z$-score, $x$ is size, $\mu$ is mean size and $\sigma$ is the standard deviation of the size). This is because references or standards for FMI and FFMI are not available for Mexican populations. In the first set of regression models we chose FFMI $\left(\mathrm{kg} / \mathrm{m}^{2}\right)$ and FMI $\left(\mathrm{kg} / \mathrm{m}^{2}\right)$ as the outcome variables and birth weight $\mathrm{z}$-scores 
as the main independent variable. To complement this analysis, a second set of multiple linear regression models were perfomed with the z-scores of the outcome variables to analyse the absolute change in the outcome variables per 1-SD change in the predictor. These models are helpful to compare the magnitude of associations between predictors and each component of body composition. Children from Motul showed higher mean values than children from Merida (6.44 $\mathrm{kg} / \mathrm{m}^{2}$ [SD=2.28] vs $5.47 \mathrm{~kg} / \mathrm{m}^{2}$ [SD=2.08], $\mathrm{p}<0.001$ ). Therefore, place of residence was introduced into the models as a co-variable. All models were adjusted for location (Merida and Motul), children's age (years), mothers' age (years), mother's BMI and household crowding index.

\section{Ethical clearance}

This research was approved by the Bioethics Committee for the Study of Human Beings of Cinvestav of Mexico and the Loughborough University Ethics Advisory Group (R11-P133). Participant mothers signed consent forms and the children gave their verbal assent.

\section{RESULTS}

The mean value for birth weight in the entire sample was $3,126 \mathrm{~g}(\mathrm{SD}=502)$ (boys: $3,144 \mathrm{~g}[\mathrm{SD}=506]$, girls: $3,108 \mathrm{~g}$ [SD $=501])$. Both boys and girls showed high levels of adiposity. The mean value for body fat mass, in all sample, was $8.6 \mathrm{~kg}$ $(S D=3.9)$, which corresponds to 31.3 units in body fat percentage $(29.9 \%$ in boys and $32.7 \%$ in girls). On average, body fat percentage increased in children at the rate of one percentual point per age group from six to eight years of age. In both boys and girls, the mean for triceps skinfold corresponded to 0.5 standard deviations above the median when compared with the Comprehensive Growth Reference data (Frisancho 2008). Boys and girls showed similar mean values in anthropometric characteristics except for the following body composition variables: i) girls showed greater values of triceps skinfolds and body fat percentage than boys; ii) boys showed greater values in fat-free mass and FFMI (Table 1). The mean number of offspring in the family was $2.4(S D=1.0) ; 48 \%$ percent of children 
included in this study were the first born, $29 \%$ were the second and $23 \%$ were the third or higher. Sixty-nine percent of the mothers were below $150 \mathrm{~cm}$ in height, which corresponds to the nearest whole centimeter of the $5^{\text {th }}$ percentile used to classify adults as short stature, and the mean value for their BMI was near to 30 $\mathrm{kg} / \mathrm{m}^{2}$, the cut-off point for obesity proposed by World Health Organization (De Onis \& Lobstein, 2010). The vast majority of mothers ( $86 \%$ ) met the criteria for excess body weight ( $42 \%$ overweigth and $44 \%$ obesity). This means that these women suffer from the double-burden of malnutrition.

Birth weight was positively associated with FFMI and FMI, but only in boys (Table 2). After adjusting for maternal characteristics, children's age and household crowding index, boys' birth weight was positively associated with increases in FFMI of $0.34 \mathrm{~kg} / \mathrm{m}^{2}$ and increases in FMl of $0.40 \mathrm{~kg} / \mathrm{m}^{2}$ per $1-S D$ increase in birth weight, respectively. These associations correspond to increases of 0.24 SD in FFMI and $0.18 \mathrm{SD}$ in FMI per 1-SD increase in boys' birth weight, which suggest that the magnitude of associations between size at birth and the two components of body composition are small and similar.

INSERT TABLE 1 HERE PLEASE INSERT TABLE 2 HERE PLEASE

\section{DISCUSSION}

In this sample of pre-pubertal Maya children, birth weight was positively associated with FFMI and FMI, but only in boys. In boys, our results show that the magnitude of associations between size at birth and lean and body fat mass during childhood are similar, which contrast with findings that birth weight is more consistently associated with subsequent lean mass than with fat mass at different ages (Wells et al., 2007).

Several studies have addressed the association between birth weight and overweight/obesity at latter ages using BMI as a measure for adiposity (e.g. Parsons, Power, Logan, \& Summerbell, 1999). However, it is well known that BMI 
correlates with both lean and body fat mass (e.g. Wellens, Roche, Khamis, Jackson, Pollock, \& Siervogel, 1996). In this study, we found that birth weight of boys is associated with both components of their body composition during childhood. This result, along with those reported by other studies, show the limitations of BMI when used to investigate the induction of fetal experience on later body compostion.

The mean birth weight of children of our sample $(3,126 \mathrm{~g})$ is similar to that reported for the Maya population in the Yucatan state (Azcorra et al. 2016) but is, on average, $200 \mathrm{~g}$ lower than that of infants included in the International Standards for Newborns Weight INTERGROWTH-21 ${ }^{\text {st }}$ Project (Villar et al. 2014) and the WHO Multicentre Growth Reference Study. However, the mean birth weight of children in our sample is higher than that reported in samples of populations from low-andmiddle income countries such as Brazil (Wells, Hallal, Wright, Singhal, \& Victora, 2005), India (Bavdekar et al. 1999) and Jamaica (Walker, Gaskin, Powell, \& Bennet, 2002), where the association between birth weight and body composition during childhood has been analysed. It is possible that higher mean birth weight in Yucatecan children may be explained by high levels of adiposity of mothers prior and during pregnancy, but we lack data to test this hypothesis. Furthermore, children in this sample show high levels of body fatness; the mean value for body fat percentage in all sample was 31.3\%. Azcorra et al. (2019) reported that $37 \%$, $32 \%$, and $26 \%$ of these children showed excessive values of BMI, waist circumference and skinfolds, respectively, taking into account age and sex. In this study, size at birth was likewise related with lean and fat mas in boys. The relationship between size at birth and subsequent lean mass seems to be well understood. Intrauterine development is an important stage in the accretion of this component of body composition mainly due to organogenesis and muscle tissue development, dominated by hyperplasic processes, predominating during the first two trimesters of pregnancy (Bernstein, Goran, Amini, \& Catalano, 1997). The relationship between birth weight and body fat later in life is more complex because fat mass accretion is present during the last trimester of pregnancy and weight gain during first years of postnatal life seems to be important for phenotype at mid- 
childhood independently of size at birth (Wells et al. 2005; Norris et al., 2020). Studies in non-human animals have showed that the induction or programming of body fatness due to maternal nutritional imbalances during pregnancy are mediated through long term changes in neuroendocrine systems that regulate energy intake and expenditure in postnatal life. Candidates of these processes include the synthesis, secretion and action of hormones such as insulin and leptin (Chang, Gaysinskaya, Karatayev, \& Leibowitz, 2008; McMillen, Muhlhausler, Duffield, \& Yuen, 2004; Remacle, Bieswal, \& Reusens, 2004).

Some studies have found an inverse association between birth weight and body fat but only after the statistical adjustments for weight or BMI are done (Malina, Katzmarzyk, \& Beunen, 1996; Garnet et al., 2001). These results have been interpreted as evidence of adiposity induction under conditions of fetal growth deficit. This interpretation has been criticized by some authors arguing that growth patterns during postnatal life, particularly weight gain, and not necessarily birth weight, should be considered the main factor for body fatness (Wells et al., 2007). Our results contrast with those reported by Rogers et al. (2006) using data from the Avon Longitudinal Study of Parents and Children (ALSPAC). In the ALSPAC, where body composition was estimated through dual-energy X-ray absorptiometry, birth weight was positively associated with total fat mass at 9-10 years of age in both sexes. To give further context, the ALSPAC sample is slightly older than the Maya children of our study, and about $37 \%$ of girls were in Tanner stage 2 of puberty at the time of the assessment. Other studies have found positive associations between birth weight and fat mass only in adult women ( $\mathrm{Li}$ et al., 2003; Sachdev et al., 2005).

Our study design and sampling strategy does not allow us to provide further explanations on why associations between birth weight and body composition were found only in boys. However, extensive evidence about how early environment shapes adult phenotype and metabolism in a sex specific manner is available (Dearden, Bouret, \& Ozane, 2018). Studies on the effects of maternal obesity in their offspring's phenotype, conducted in human and non-human animals, have 
shown that males tend to be more susceptible than females to accumulate body fat in response to maternal overnutrition during pregnancy (Andres et al., 2015; Pankey et al., 2017). Furthermore, some studies have found that infants born to overweight/obese mothers had more fat mass and less fat-free mass compared to infants born to normal weight mothers (e.g. Hull, Dinger, Knehans, Thompson, \& Fields, 2008). Increased susceptibility of males against adverse early environments is not limited to conditions experienced during gestation. Some studies done with mice have found that males have higher absolute and relative weight gain and fat mass indexes than females when are exposed to high fat diets (Estrany, Proenza, Lladó, \& Gianotti, 2011; Grove, Fried, Greenberg, Xiao, \& Clegg, 2010). Our results on the association between birth weight and body composition in boys are in line with the notion about the strong influence of maternal phenotype on male offsprings' body composition, particularly in the context of the Maya population where women's overweight and obesity rates are very high (Azcorra, Varela-Silva, Rodriguez, Bogin, \& Dickinson, 2013). Results of a previous study with this sample indicate that body fat percentage of children's mothers is about 45\% (Azcorra et al., 2019). Besides, results of a study that aimed to investigate the quality of maternal diet during pregnancy in a sample of women from low to middle income groups from Merida and surrounded communities, found that $51 \%$ of women started the pregnancy with excess body weight $\left(\mathrm{BMl}>25 \mathrm{~kg} / \mathrm{m}^{2}\right.$ ) (Romero Villanueva, 2020). The notion of an increased susceptibily of boys in this sample against adverse early conditions and intergenerational influences is supported by results of a previous study in which maternal height, a proxy measure for nutritional history, was inversely associated with fat mass index, waist circumference and skinfolds in boys (Azcorra, Dickinson, \& Datta Banik, 2016).

Our results might be also explained by sex differences in body composition. It is known that sexual dimorphism regarding the amount and distribution of body fat and lean mass is established early in fetal life, and that by birth, females have less lean mass than males (Wells, 2007b). This sexual dimorphism, stable along infancy and childhood, increases at puberty. By puberty, girls tend to increase their fat mass content, both in absolute $(\mathrm{kg})$ and relative $(\%)$ terms, while boys tend to 
keep increasing lean body mass (Bogin, 1999). The girls from our sample show higher levels of body fat percentage (32.7\% vs $29.9 \%)$ and lower values of fat-free mass than boys $\left(11.8 \mathrm{~kg} / \mathrm{m}^{2}\right.$ vs $\left.12.5 \mathrm{~kg} / \mathrm{m}^{2}\right)$. However, as far as we know, there are no reports of sexual dimorphism in body composition of Maya children during childhood obtained from longitudinal studies. Differences in the development of adiposity and lean body mass between males and females may be associated to a major resistance on females to induction processes in the presence of adverse conditions experienced prenatally and postnatally. From an evolutionary point of view, our results might be interpreted as evidence of how unfavorable conditions experienced in early stages of development impact offspring's metabolism and phenotype in a sex specific manner; this biological process could increase reproductive fitness. Some studies have found positive associations between size at birth and body fat mass only in adult women (Li et al. 2003; Sachdev et al., 2005). These results have been interpreted as differential strategies established between males and females since intrauterine development to allocate somatic tissue and energy stores (lean mass in males and body fat in females) in preparation for reproductive cost (Wells et al., 2007).

To the best of our knowledge, there are no reports from ethnographic studies showing that Maya children from Yucatan receive gendered differential feeding and provision of health care. Our own experience of several decades working in the field also does not indicate that associations between birth weight and body compostion found in boys are product of differential treatment by sex.

Overweight and obesity are health problems with a high cost in the well-being of indigenous populations, such as the Maya. On average, eight out of ten adult Maya women and four out of ten school-age children meet the criteria for excessive body weight. The actions implemented by Yucatec health institutions to reduce overweight figures among the Maya have focused, with very little success, on changing behaviors at the individual level and on building healthier environments. The results of our study show that phenotype observed in childhood, when several metabolic pathways have been established, is shaped by conditions experienced 
at very early stages of development and by maternal nutritional history, including her prenatal and postnatal growth. Even though the magnitude of the associations between birth weight and body composition found in this study is small, our results indicate the need for early actions such as improving the growth and nutritional status of girls during infancy and reducing obesity among adult women before reproduction, taking into account that some positive results in the phenotype and health status will be observed in later generations. These actions must be framed in policies that seek to reduce the levels of poverty and discrimination and increase access to quality health services among the indigenous populations.

\section{Limitations}

Limitations in this study includes the lack of data about maternal characteristics before and during pregnancy. Statistical models on the association between children's birth weight and body composition were adjusted for maternal BMI at the time of the study, that is to say, 6 to 8 years after children's birth. Several factors may have influenced current maternal phenotype including reproduction and aging. Unfortunately, we lack of data on maternal body composition before conception and weight gain during pregnancy, factors that may help to understand more clearly process of induction of body composition.

\section{Conclusion}

The main results of this study show that urban Maya children of this sample exhibit high levels of adiposity and that size at birth was positively associated with lean and body fat mass in boys during childhood in contrast with previous findings that birth weight is more consistently associated with subsequent lean mass than with fat mass. Associations detected only in boys may be explained by sex differences in susceptibility to ecological conditions experienced in early stages of development and differences in the development of adiposity and lean body mass between males and females during mid-childhood. Our results indicate the need for 
actions to be taken at very early stages of life in order to mitigate the burden of disease caused by overweight and obesity among the Maya.

\section{ACKNOWLEDGMENTS}

Mexican Conacyt funded the research project (contract grant 168047) and the Ph. D. studentship of HA (contract grant: 308942). Graciela Valentin supported us in standardization of anthropometric techniques and field work.

The authors declare no conflict of interest.

\section{AUTHOR CONTRIBUTIONS}

HA formulated the research question, analyzed the data and wrote the first draft of the manuscript; MIVS and FD contributed to the first and subsequent drafts and provided input on all sections of the paper.

\section{References}

Andres, A., Hull, H. R., Shankar, K., Casey, P. H., Cleves, M. A., \& Badger, T. M. (2015). Longitudinal body composition of children born to mothers with normal weight, overweight, and obesity. Obesity, 23(6), 1252-1258.

Azcorra, H., Dickinson, F., \& Datta Banik, S. (2016). Maternal height and its relationship to offspring birth weight and adiposity in 6- to 10-year-old Maya children from poor neighbourhoods in Merida, Yucatan. American Journal of Physical Anthropology, 161(4):571-571.

Azcorra, H., Vázquez-Vazquez, A., Mendez, N., Salazar, J. C., Datta-Banik, S. (2016). Maternal Maya ancestry and birth weight in Yucatan, Mexico. American Journal of Human Biology, 28(3):436-439.

Azcorra, H., Varela-Silva, M. I., Rodríguez, L., Bogin, B., \& Dickinson, F. (2013). Nutritional status of Maya children, their mothers, and their grandmothers residing in the city of Merida, Mexico: revisiting the leg-length hypothesis. American Journal of Human Biology, 25(5):659-665. 
Azcorra, H., Rodríguez, L., Datta Banik, S., Bogin, B., Varela-Silva, M. I., \& Dickinson F. (2019). Caesarean birth and adiposity parameters in 6-to-8 year old urban Maya children from two cities of Yucatan, Mexico. American Journal of Human Biology, 31(2):e23217.

Bateson, P. (2001). Fetal experience and good adult design. International Journal of Epidemiology, 30(5), 928-934.

Bavdekar, A., Yajnik, C. S., Fall, C. H., Bapat, S., Pandit, A. N., Deshpande, V., Bhave, S., Kellingray, S. D., \& Joglekar, C. (1999). Insulin resistance syndrome in 8 -year-old Indian children: small at birth, big at 8 years, or both? Diabetes, 48(12), 2422-2429.

Bernstein, I. M., Goran. M. I., Amini, S. B., \& Catalano, P. M. (1997). Differential growth of fetal tissues during the second half of pregnancy. American Journal of Obstetricts \& Gynecology, 176(1), 28-32.

Bogin, B. (1999). Patterns of human growth. Cambridge: Cambridge University Press.

Bogin, B., Avila-Escalante, M. L., Castillo-Burguete, M. T., Azcorra, H., \& Dickinson, F. (2020). Globalization and children's diets: The case of Yucatan, Mexico. In: Azcorra H, Dickinson F (editors). Culture, environment and health in the Yucatan Peninsula. A human ecology perspective. Springer.

Bracamonte, P. (2007). Una deuda histórica. Ensayo sobre las causas de pobreza secular de los mayas yucatecos. México, D. F.: CIESAS-Porrúa-ICY.

Bracamonte, P., \& Lizama, J. (2006). Tocando fondo. Resultados básicos de la encuesta sobre marginalidad, pobreza e identidad del pueblo maya (EMPIMAYA 2004). México, D. F.: CIESAS-Colección Peninsular.

Calella, P., Galle, F., Fornelli, G., Liguori, G., \& Valerio, G. (2020). Type 1 diabetes and body composition in youth: A systematic review. Diabetes Metabolism Research and Reviews, 36(1):e3211.

Chang, G. Q., Gaysinskaya, V., Karatayev, O., \& Leibowitz, S. F. (2008). Maternal high-fat diet and fetal programming: increased proliferation of hypothalamic peptide-production neurons that increase risk for overeating and obesity. Journal of Neuroscience, 28(46), 12107-12119. 
CDI. (2017). Indicadores socioeconómicos de los pueblos indígenas de México. Comisión Nacional para el Desarrollo de los Pueblos Indígenas. Available at https://www.gob.mx/cms/uploads/attachment/file/239923/04-estimacionesnacionales-por-entidad-federativa.pdf. Accessed June 15, 2020.

Colantonio, S., Lasker, G. W., Kaplan, B. A., \& Fuster, V. (2003). Use of surname models in human population biology: A review of recent developments. Human Biology, 75(6), 785-807.

Dearden, L., Bouret, S. G., \& Ozanne, S. E. (2018). Sex and gender differences in developmental programming of metabolism. Molecular Metabolism, 15, 8-19.

De Onis, M., \& Lobstein, T. (2010). Defining obesity risk status in the general childhood population: which cutoffs should we use? International Journal Pediatric Obesity, 5(6), 458-460.

Dickinson, F., Cervera, M. D., Murguia, R., \& Uc, L. (1990). Growth, nutritional status and environmental change in Yucatan, Mexico. Studies in Human Ecology, 9,135-149.

Estrany, M. E., Proenza, A. M., Lladó, I., \& Gianotti, M. (2011). Isocaloric intake of a high-fat diet modifies adiposity and lipid handling in a sex dependent manner in rats. Lipids in Health and Disease, 10:52.

Fewtrell, M. S., Lucas, A., Cole, T. J., \& Wells, J. C. K. (2004). Prematurity and reduced body fatness at 8-12 y of age. American Journal of Clinical Nutrition, 80(2), 436-440.

Frisancho, A. R. (2008). Anthropometric standards: An interactive nutritional reference of body size and body composition for children and adults. Ann Arbor, MI: The University of Michigan Press.

Garnett, S. P., Cowell, C. T., Baur, L. A., Fay, R. A., Lee, J., Coakley, J., ... Boulton, T. J. (2001). Abdominal fat and birth size in healthy prepubertal children. International Journal of Obesity, 25(11), 1667-1673.

Grove, K. L., Fried, S. K., Greenberg, A. S., Xiao, X. Q., \& Clegg, D. J. (2010). A microarray analysis of sexual dimorphism of adipose tissues in high-fat-dietinduced obese mice. International Journal of Obessity, 34(6), 989-1000. 
Hull, H. R., Dinger, M. K., Knehans, A. W., Thompson, D. M., \& Fields, D. A. (2008). Impact of maternal body mass index on neonate birthweight and body composition. American Journal of Obstetrics \& Gynecology, 198(4), 416.e1-6.

INEGI. (2015a). Hablantes de lengua indígena en Yucatán. Instituto Nacional de Estadística y Geografía. Available at https://www.inegi.org.mx/app/indicadores/?t=020000600010\&ag=31

Accessed September, 2020.

INEGI. (2015b). Caracteristicas educativas de la población. Yucatán. Instituto Nacional de Estadística y Geografía. Available at:

https://www.inegi.org.mx/app/indicadores/?t=00600010\&ag=31\#D006000100020\# divFV6207019026 Accesed September 2020.

Krieger, J., \& Higgins, D. L. (2002). Housing and health: time again for public health action. American Journal of Public Health, 92(5), 758-768.

Kuzawa, C. W. (1998). Adipose tissue in human infancy and childhood: An evolutionary perspective. Yearbook of Physical Anthropology, 41, 177-209.

Lätt, E., Mäestu, J., \& Jürimäe, J. (2018). Longitudinal associations of android and gynoid fat mass on cardiovascular disease risk factors in normal weight and overweight boys during puberty. American Journal of Human Biology, 30(5):e23171.

Li, H., Stein, A. D., Barnhart, H, X., Ramakrishnan, U., \& Martorell, R. (2003). Associations between prenatal and postnatal growth and adult body size and composition. American Journal of Clinical Nutrition, 77(6), 1498-1505.

Lohman, T. G., Roche, A. F., \& Martorell, R. (1988). Anthropometric standardization reference manual. Champaign, IL: Human Kinetics Books.

Malina, R. M., Katzmarzyk, P. T., \& Beunen G. (1996). Birth weight and its relationship to size attained and relative fat distribution at 7 to 12 years of age. Obesity Research, 4(4), 385-390.

McMillen, I. C., Muhlhausler, B. S., Duffield, J. A., \& Yuen, B. S. (2004). Prenatal programming of postnatal obesity: fetal nutrition and the regulation of leptin synthesis and secretion before birth. Proceedings of the Nutrition Society, 63(3), 405-412. 
Metges, C. C. (2009). Early nutrition and later obesity: Animal models provide insights into mechanisms. In: Koletzko B, Decsi T, Molnar D, and de la Hunty A. (eds) Early nutrition programming and health outcomes in later life. Obesity and beyond. Springer.

Norris, T., Crozier, S. R., Cameron, N., Godfrey, K. M., Inskip, H., \& Johnson, W. (2020). Fetal growth does not modify the relationship of infant weight gain with childhood adiposity and blood pressure in the Southampton women's survey. Annals of Human Biology, 47(2), 150-158.

Okosun, I. S., Liao, Y., Rotimi, C. N., Dever, G. E., \& Cooper, R. S. (2000). Impact of birth weight on ethnic variations in subcutaneous and central adiposity in American children aged 5-11 years. A study from the Third National Health and Nutrition Examination Survey. International Journal of Obesity and Related Metabolic Disorders, 24(4), 479-484.

Pankey, C. L., Walton, M. W., Odhiambo, J. F., Smith, A. M., Ghenenis, A. B., Nathanielsz, P. W., \& Ford, S. P. (2017). Intergenerational impact of maternal overnutrition and obesity throughout pregnancy in sheep on metabolic syndrome in grandsons and granddaughters. Domestic Animal Endocrinology, 60, 67-74.

Parsons, T. J., Power C., Logan, S., \& Summerbell, C. D. (1999). Childhood predictors of adult obesity: a systematic review. International Journal of Obesity and Related Metabolic Disorders, 23(8), S1-S107.

Ramírez-Carrillo, L. A. (2020). The thin broken line. History, society, and the environment on the Yucatan Peninsula. In: Azcorra H, and Dickinson F, (editors) Culture, environment and health in the Yucatan Peninsula. A human ecology perspective. Springer.

Ramírez, E., Valencia, M. E., Bourges, H., Espinosa, T., Moya-Camarena, S. Y., Salazar, G., \& Aleman-Mateo, H. (2012). Body composition prediction equations based on deuterium oxide dilution method in Mexican children: A national study. European Journal of Clinical Nutrition, 66(10), 1099-1103.

Relethford, J. H. (1995). The use of surnames in the study of human variation and plasticity. In: Mascie-Taylor GCN and Bogin B, (editors) Human variability and plasticity. Cambridge: Cambridge University Press. 
Remacle, C., Bieswal, F., \& Reusens, B. (2004). Programming of obesity and cardiovascular disease. International Journal of Obesity and Related Metabolic Disorders, 28(3), S46-S53.

Rogers, I. S., Ness, A. R., Steer, C. D., Wells, J. C., Emmett, P. M., Reilly, J. R., Tobias, J., \& Smith, G. D. (2006). Associations of size at birth and dual-energy Xray absorptiometry measures of lean and fat mass at 9 to $10 \mathrm{y}$ of age. American Journal of Clinical Nutrition, 84(4):739-47.

Romero Villanueva, D. E. (2020). Factores asociados a la selección y consumo durante el embarazo. Master degree thesis. Departamento de Ecología Humana. Centro de Investigación y de Estudios Avanzados del Instituto Politécnico Nacional, https://www.mda.cinvestav.mx/Posgrados/Maestr\%C3\%ADaenEcolog\%C3\%ADaH umana/Tesis.aspx, tesis number 116. Accesed 5 November 2020.

Sachdev, H. S., Fall, C. H., Osmond, C., Lakshmy, R., Dey Biswas, S. K., Leary, S. D., Reddy, K. S., Barker, D. J., \& Bhargava, S. K. (2005). Anthropometric indicators of body composition in young adults: relation to size at birth and serial measurements of body mass index in childhood in the New Delhi birth cohort. American Journal of Clinical Nutrition, 82(2), 456-466.

Villar, J., Ismail, L. C., Victora, C. G., Ohuma, E. O., Bertino, E., Altman, D. G., ... the International Fetal and Newborn Growth Consortium for the $21^{\text {st }}$ Century (INTERGROWTH-21 ${ }^{\text {st }}$ ). (2014). International standards for newborn weight, length, and head circumference by gestational age and sex: the Newborn Cross-Sectional Study of the INTERGROWTH-21 ${ }^{\text {st }}$ Project. Lancet, 384(9946), 857-868.

Walker, S. P., Gaskin, P. S., Powell, C. A., \& Bennett, F. I. (2002). The effects of birth weight and postnatal linear growth retardation on body mass index, fatness and fat distribution in mid and late childhood. Public Health Nutrition, 5(3), 391-396.

Wellens, R. I., Roche, A. F., Khamis, H. J., Jackson, A. S., Pollock, M. L., \& Siervogel, R. M. (1996). Relationships between the body mass index and body composition. Obesity Research, 4(1), 35-44.

Wells, J. C. K. (2007a). The programming effects of early growth. Early Human Development, 83(12), 743-748.

Wells, J. C. K. (2007b). Sexual dimorphism of body composition. Best Practice \& Research Clinical Endocrinology and Metabolism, 21(3), 415-430. 
Wells, J. C. K. (2012). The concept of phenotypic induction ('Programming) and implications for growth. In: Preedy V. (editor) Handbook of growth and growth monitoring in health and disease. Springer, New York, NY.

Wells, J. C. K., Chomto, S., \& Fewtrell, M. (2007). Programming of body composition by early growth and nutrition. Proceedings of the Nutrition Society, 66(3), 423-434.

Wells, J. C. K., Hallal, P., Wright, A., Singhal, A., \& Victora, C. G. (2005). Fetal, infant and childhood growth: relationships with body composition in Brazilian boys aged 9 years. International Journal of Obesity, 29(10), 1192-1198. 
Table 1 Anthropometric and body composition characteristics of participants

\begin{tabular}{|c|c|c|c|c|}
\hline Characteristics & All sample & $\begin{array}{c}\text { Boys }(n=132) \\
\text { Mean }(S D)\end{array}$ & $\begin{array}{c}\text { Girls }(n=128) \\
\text { Mean }(S D)\end{array}$ & $P$ \\
\hline \multicolumn{5}{|l|}{ Children } \\
\hline Age (years) & $7.5(0.8)$ & $7.6(0.8)$ & $7.5(0.8)$ & 0.570 \\
\hline Birth weight $(\mathrm{kg})$ & $3126(502)$ & $3144(506)$ & $3108(501)$ & 0.569 \\
\hline Height $(\mathrm{cm})$ & $120.5(7.1)$ & $120.9(7.0)$ & $120.2(7.1)$ & 0.416 \\
\hline Weight $(\mathrm{kg})$ & $26.4(6.9)$ & $26.8(7.0)$ & $26.1(6.9)$ & 0.376 \\
\hline BMI $\left(\mathrm{kg} / \mathrm{m}^{2}\right)$ & $17.9(3.1)$ & $18.1(3.2)$ & $17.8(3.1)$ & 0.435 \\
\hline Triceps skinfold (mm) & $12.2(4.74)$ & $11.4(4.66)$ & $12.9(4.70)$ & 0.006 \\
\hline \multicolumn{5}{|c|}{ Body composition - Bioelectrical impedance analysis } \\
\hline Fat-free mass $(\mathrm{kg})$ & $17.9(3.5)$ & $18.5(3.6)$ & $17.2(3.4)$ & 0.005 \\
\hline Fat mas $(\mathrm{kg})$ & $8.6(3.9)$ & $8.3(3.8)$ & $8.8(3.9)$ & 0.326 \\
\hline$\% \mathrm{BF}$ & $31.3(6.3)$ & $29.9(6.3)$ & $32.7(6.0)$ & $<0.001$ \\
\hline FFMl $\left(\mathrm{kg} / \mathrm{m}^{2}\right)$ & $12.2(1.4)$ & $12.5(1.4)$ & $11.8(1.4)$ & $<0.001$ \\
\hline \multicolumn{5}{|l|}{ Mothers } \\
\hline Age (years) & $33(5.5)$ & 32.9 & $33.1(5.8)$ & 0.751 \\
\hline Height $(\mathrm{cm})$ & $147.8(4.9)$ & $147.4(5.1)$ & $148.3(4.8)$ & 0.153 \\
\hline Weight $(\mathrm{kg})$ & $65.1(11.6)$ & 65 (11.7) & $65.2(11.6)$ & 0.926 \\
\hline BMI $\left(\mathrm{kg} / \mathrm{m}^{2}\right)$ & $29.7(4.7)$ & $29.9(4.8)$ & $29.6(4.7)$ & 0.603 \\
\hline \multicolumn{5}{|l|}{ Household } \\
\hline Crowding index & $3.1(1.4)$ & $3.1(1.4)$ & $3.1(1.5)$ & 0.970 \\
\hline
\end{tabular}

FFMI: fat-free mass index; FMI: fat mass index; \%BF: body fat percentage. Independent t-test was applied to compare mean values of anthropometric variables and body composition parameters between boys and girls. 
Table 2 Associations of birth weight (z-score) with fat-free mass index and fat mass index estimated from bioelectric impedance analysis.

\begin{tabular}{|c|c|c|c|c|c|c|c|}
\hline \multirow[t]{2}{*}{ Outcomes } & \multicolumn{3}{|c|}{ Boys } & \multicolumn{4}{|c|}{ Girls } \\
\hline & B (SE) & $95 \% \mathrm{Cl}$ & $\mathrm{P}$ & B (SE) & $95^{\circ}$ & $\mathrm{Cl}$ & $P$ \\
\hline Fat free mass index $\left(\mathrm{kg} / \mathrm{m}^{2}\right)$ & $0.34(0.11)$ & 0.110 .56 & 0.003 & $0.18(0.11)$ & -0.04 & 0.40 & 0.203 \\
\hline Fat mass index $\left(\mathrm{kg} / \mathrm{m}^{2}\right)$ & $0.40(0.16)$ & $0.07 \quad 0.71$ & 0.018 & $0.15(0.18)$ & -0.21 & 0.50 & 0.430 \\
\hline
\end{tabular}

Each row represents a different model with children's FFMI and FMI in the left hand column as the dependent variables and birth weight (z-score) as the main independent variable. All models were adjusted for location, children's age and mothers' age and BMI and household overcrowding index. 